\title{
Work Satisfaction In Compensation Mediation and Motivation on Productivity Permanent Employees of Pt. Sinergi Mitra Utama in Bandung
}

\author{
Imelda Indrawati Syaifullah, Purnamie Titisari, Novi Puspitasari
}

Jember University, Faculty of Economics and Business,

J1. Kalimantan No. 37, Campus Tegalboto, Jember, East Java, 68121, Indonesia

\begin{abstract}
:
The purpose of this study was to analyze the effect of compensation and motivation on job satisfaction and productivity of permanent employees at PT. Sinergi Mitra Utama in Bandung. This research is included in explanatory research. The population of this research is all permanent employees of the company PT. Sinergi Mitra Utama in Bandung, 35 employees. Based on predetermined criteria, the total sample of this study is 35 employees. Data analysis was done using path analysis. After analyzing data, several conclusions can be taken, that is : a). Work compensation has a significant direct effect on job satisfaction, b). Motivation has a significant positive effect on employee work productivity, c). Work compensation has a significant positive direct effect on job satisfaction, d). Motivation has a significant positive effect on employee job satisfaction, e). Job satisfaction has a significant positive effect on work productivity, f). Compensation affects work productivity through job satisfaction, g). work motivation has a significant positive effect on work productivity through job satisfaction.
\end{abstract}

Keywords: compensation, motivation, satisfaction, employee productivity.

\section{Introduction}

Competition in an increasingly competitive business world forces companies to be able to manage and process all of their resources effectively and efficiently so that they can survive and develop. Good corporate management is carried out with the right management. Performance management is a part of continuous communication between employees and leaders. Good performance management will produce a solid teamwork. Work management is well formed if it is supported by optimal and maximum resources. The resources in question can come from human resources. Effective human resource management will increase the target as per the company standard.

Companies have many factors to be able to influence human resources in achieving job satisfaction and predetermined goals, namely increasing productivity. These factors can be in the form of compensation and motivation. Compensation is all opinions in the form of money, goods directly or indirectly received by employees in return for services provided to the company. Motivation is the power of the tendency of an individual to engage in activities that are targeted at work. This is not a feeling of pleasure relative to the results of various jobs as well as job satisfaction, but rather a feeling of being willing to work to achieve satisfying work goals. This is a complete realization of one's full potential. Employees who get compensation according to their rights and motivation are expected to increase job satisfaction and productivity.

Job satisfaction is quite interesting and important, because it's proven benefits for the interests of individuals, industry, and society. For individuals, research on the causes and sources of job satisfaction enables the emergence of efforts to increase their happiness in life. Every company should keep maintaining work satisfaction, so that employees can achieve in the form of providing maximum work productivity. The Productivity of employee work for a company is very important as a means of measuring success in running a business. Because the higher the work productivity of employees in the company, means that corporate profits and productivity will increase. The International Labor Organization (ILO) (Hasibuan, 2009: 127) reveals the more simply the purpose of productivity is a comparison in arithmetic between 
the amount produced and the number of each source used during production.

Research by Retnoningsih et al. (2016), shows that financial compensation has an effect on employee job satisfaction, financial compensation has an effect on job satisfaction, financial compensation affects employee performance, financial compensation has an effect on employee performance, employee job satisfaction affects employee performance. Widyawati and Verawati (2016) found that compensation and job satisfaction of employees provide a positive and significant influence on employee performance. Employee satisfaction is able to mediate compensation associations with employee performance.

PT. Sinergi Mitra Utama in Bandung is a company that produces riding motorcycle apparel. The company has vision to be an innovation company that prioritizes technology in the development of motorcycle apparels and cycling products, focusing on safety, comfort, and lifestyle in tropical countries. PT. Sinergi Mitra Utama in Bandung is a company engaged in the production of driving apparel such as men's jackets, women's jackets, gloves, masks, touring pants, and more complete touring shoes for motorbikes driving.

PT. Sinergi Mitra Utama in Bandung must ensure that the compensation system meets the criteria that are feasible and sufficient. PT. Sinergi of Respiro Brand Partners in Bandung has a vision and mission that must be carried out. Implementation, PT. Sinergi Mitra Utama in Bandung is managed and regulated by humans as a strategic resource in organizational activities. PT. Sinergi Mitra Utama in Bandung can improve the welfare of employees and their communities, so that the Company must prepare itself as well as possible so that it can play an active role in the welfare of employees.

PT. Sinergi Mitra Utama in Bandung has a problem that has an impact on the survival of the company; one of the problems is the low compliance of employees in carrying out the Standard Operating Procedure (SOP). Lack of adherence to SOP can result in low work productivity. Of the various types of businesses increasing employee work productivity, one of them has done by the company is providing job satisfaction for employees and company needs, also compensation and motivation. High productivity is the goal of every company/ organization, because high productivity can make companies/ organizations more productive and employees can complete their work on time. There before the goals of the company/ organization can be achieved well. Giving compensation and motivation by PT. Sinergi Mitra Utama in Bandung is expected to create employee job satisfaction and work productivity of the company.

PT. Sinergi Mitra Utama in Bandung must be able to run their business optimally. The success of the Company in achieving its objectives is determined by the active role of all components of human resources, especially in the work productivity of the organization's employees. For example, start from organizational work productivity problems that occur in PT. Sinergi Mitra Utama in Bandung. The work productivity that exists in an organization causes employees and employees to have the same perspective in carrying out employee activities. Existing problems such as employee disobedience to SOP can be minimized by providing compensation and motivation.

\section{Literature Review}

\subsection{Effect of Compensation on Job Satisfaction}

Employees will feel that the work they do in working for a paid or valued company is worth the compensation they have received, therefore employees will feel satisfied. Retnoningsih et al. (2016), found that financial compensation has an effect on employee job satisfaction, financial compensation has an effect on job satisfaction, financial compensation affects employee performances, financial compensation has an effect on employee performances, employee job satisfaction affects employee performance. Widyawati and Verawati (2016) found that employee compensation and job satisfaction had a positive and significant influence on employee performance. Employee satisfaction is able to mediate compensation associations with employee performance.

H1: Compensation has a significant positive effect on employee job satisfaction.

\subsection{Effect of Motivation on Job Satisfaction}

Motivated employees will feel work satisfaction in their work so that they can improve their performance and influence service delivery (Sarwar and Abugre, 2013) to the community in accordance with the fields of their respective departmental duties and functions. Saleem et al (2010), found that companies must consider the importance of employee job satisfaction and its effect on organizational effectiveness and productivity, management and company teachers must take such 
necessary actions. Kurnia et al (2015) found that for Job Satisfaction (Y1) the hypothesis was proven and acceptable. The influence is significant, so that the work motivation given by PT. ASKES (Persero) Cab. Boyolali to employees will be able to give satisfaction to work better.

$\mathrm{H} 2$ : Work motivation has a positive significant effect on employee job satisfaction.

\subsection{Effect of Compensation on Work Productivity}

One way to motivate employees to be able to increase work productivity is by providing appropriate compensation from the company. Motivation will arise from within employees to work as well as possible if the wages they provide feel right. Thus, compensation can affect the increase in employee productivity. Kelechi et al (2016) found that many private companies and public organizations must do justice to all compensation issues. Sutriani (2017) found that financial compensation and non-financial compensation variables simultaneously had a positive and significant influence on employee productivity.

H3: Compensation has a positive significant effect on employee work productivity.

\subsection{Effect of Motivation on Work Productivity}

According to Siagian (1985: 128), describe that the whole process of giving motivation to subordinates in such a way, sincerely in order to achieve organizational goals effectively and efficiently. Work situations that can affect work motivation are company policies such as wage scales and employee benefits. Hamali (2013) found that motivation has a fairly good category and good work productivity. The results showed the effect of motivation on work productivity of employees at PT. X Bandung is very strong. Narimo (2005) found that Motivation has a significant negative influence on productivity and inspection variables that have a significant positive effect on productivity. Productivity is very dependent on the motivation of the company and will be achieved if there is high motivation and good morale from its human resources.

H4: Work motivation has a positive significant effect on employee work productivity.

2.5 Effect of Job Satisfaction on Work Productivity

High productivity causes an increase in job satisfaction only if the workforce perceives that what the company has achieved is in accordance with what they receive (salary/ wages) which is fair and reasonable and is associated with superior work performance. Sarwar and Abugre (2014) found that job satisfaction affects work productivity. Different from Muayyad (2016), who found that job satisfaction did not have a significant effect on employee productivity. Kinasih (2015), found that job satisfaction affects work productivity.

H5: Job satisfaction has a positive significant effect on employee work productivity.

\subsection{Effect of Compensation on Productivity through} Job Satisfaction

Giving compensation by the company to employees will be able to increase labor productivity. This happens because employees feel satisfied with their work. The higher job satisfaction felt by employees, the productivity also increases. So that satisfaction is able to mediate between compensation and work productivity. Compensation is often used as a tool to encourage or motivate employees to be more qualified in terms of productivity so that what is the goal of the company is achieved. Therefore, if it is not followed by good compensation, it can reduce employee work. Simamora (2004: 442) states that compensation is what received by employees in exchange for their contribution to the organization. Compensation is the most important thing in the company's management system, without compensation for the company's growth rate will be slow. For this reason, we need a way to build employee performance to improve work productivity. This is very rational because it involves personal needs, whoever it is and whatever it is. Compensation is given solely for the welfare of employees and as a tool to build employee motivation and spirit to produce better performance.

H6: Compensation has a positive significant effect on work productivity through employee job satisfaction.

2.7 Effect of Motivation on Productivity through Job Satisfaction

The emergence of work motivation is influenced by several driving factors, both from within and from outside the individual employee itself. Motivation encourages employees to work effectively and efficiently differently among employees. This difference is caused by differences 
in motivation, goals, and needs of each employee to work, and also due to differences in time and place. Motivated employees will automatically increase their productivity. This is because there is satisfaction felt after being given motivation. If given motivation is not been noticed, then there will be no enthusiasm and passion to work. Therefore, it will also affect the work productivity of employees. Work motivation is a condition where employees need full appreciation for their work; get a comfortable atmosphere in work, security in work, good salary/wages, attractive work and wise discipline from each manager. One of the factors that affect work productivity is lack of employee morale where one of them is a problem of lack of work motivation done by a company manager. Work motivation is a condition or situation in a company that wants to increase profits greater than before, therefore work motivation is very important in getting maximum productivity. Because the purpose of work motivation is to provide work spirit to each employee so that employees can carry out their duties effectively and efficiently. The impact occurs if there is no work motivation in the company, where employees will do their jobs with mediocrity and lack of enthusiasm in carrying out their duties.

H7: Motivation has a significant positive effect on work productivity through employee job satisfaction.

\section{Research Methods}

This research is included in explanatory research. The population of this research is all permanent employees of the company PT. Sinergi Mitra Utama in Bandung, 35 employees. Based on predetermined criteria, the total sample of this study is 35 employees. Data analysis was done using path analysis.

a. First hypothesis (H1)

The t-test results show that $\mathrm{T}$-count $>\mathrm{T}$ table and sig value $<0.05$, $(2.934>2.032$ and $0.011<0.05)$ then $\mathrm{HO}$ (null hypothesis) is rejected and Ha (alternative hypothesis) is accepted i.e. compensation has a significant positive effect on employee job satisfaction.

b. Second Hypothesis (H2)

T-test results show that $\mathrm{T}$-count $>\mathrm{T}$ table and sig value $<0.05(4.555>2.032$ and $0.000<0.05)$, then $\mathrm{HO}$ (null hypothesis) is rejected and Ha (alternative hypothesis) is accepted or work motivation has a significant positive effect on job satisfaction employee.

c. Third Hypothesis (H3).
The $\mathrm{t}$-test results show that $\mathrm{T}$-count $>\mathrm{t}$ table and sig value $<0.05$ (4.684> 2.032 and $0.000<0.05)$, then $\mathrm{HO}$ (null hypothesis) is rejected and Ha (alternative hypothesis) is accepted or compensation has a significant positive effect on employee work productivity.

d. Fourth Hypothesis (H4).

T-test results show that $\mathrm{T}$-count $>\mathrm{t}$ table and sig value $<0.05$ (2.687> 2.032 and $0.011<0.05)$, then $\mathrm{HO}$ (null hypothesis) is rejected and Ha (alternative hypothesis) is accepted or work motivation has a significant positive effect on work productivity.

e. Fifth Hypothesis (H5).

$\mathrm{T}$ test results show that $\mathrm{T}$-count $>\mathrm{t}$ table and sig value $<0.05$ (3.069> 2.032 and $0.004<0.05)$, then $\mathrm{H} 0$ (null hypothesis) is rejected and Ha (alternative hypothesis) is accepted or job satisfaction has a significant effect on employee work productivity.

\section{Path Calculation}

The Path Analysis model after regression analysis can be presented as follows:

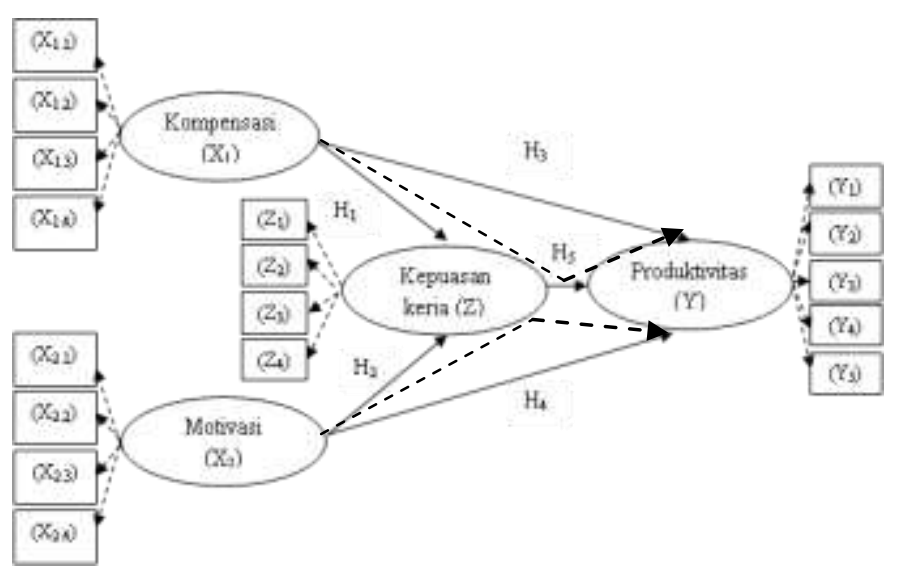

Figure : Conceptual Model

Furthermore, this section describes the calculation of the comparison of the direct effect of the Compensation variable (X1) on work productivity $(\mathrm{Y})$, the direct influence between work motivation (X2) on work productivity

$(Y)$, the direct effect of job satisfaction $(\mathrm{Z})$ on work productivity

(Y ) and the indirect effect of Compensation (X1) on work Productivity

(Y) through intervening variables Job Satisfaction (Z) and indirect effects of work motivation (X2) on work productivity $(\mathrm{Y})$ through intervening variables Job Satisfaction (Z).

a. Direct Effect (Direct Effect or DE):

1)Variable Compensation (X1) effect on job satisfaction $(Z)$

$\mathrm{DEx} 1 \mathrm{z}=\mathrm{X} 1 \quad \square \quad \mathrm{Y}$ 
$\operatorname{Dex} 1 z=0,361$

2)Effect of work motivation variable (X2) on job satisfaction $(Z)$

$\operatorname{DEx} 2 \mathrm{z}=\mathrm{X} 1 \rightarrow \mathrm{Z}$

$\operatorname{DEx} 2 z=0,581$

3)Variable Compensation (X1) effect on work productivity (Y)

DEx1y $=\mathrm{X} 1->\mathrm{Y}$

Dex $1 \mathrm{y}=0,581$

4)Effect of work motivation variable (X2) on work productivity $(\mathrm{Y})$

$\operatorname{Dex} 2 \mathrm{Z}=\mathrm{Z}->\mathrm{Y}$

$\operatorname{Dex} 2 z=0,485$

5)Effect of variable Job Satisfaction (Z) on work productivity $(\mathrm{Y})$

DEzy $=\mathrm{X} 2->\mathrm{Y}$

DEzy $=0,485$

b. Indirect Effect (IE Effect):

1. Indirect influence between Compensation (X1) on work productivity (Y) through intervening variables Job Satisfaction (Z).

IEYZx1 = X1-> Z ->Y

$\operatorname{IEYZx1}=(0,581)+\{(0,361 \times 0,485)\}$ $=0,756$

2. Indirect influence between work motivation (X2) on work productivity (Y) through intervening variables Job Satisfaction $(\mathrm{Z})$.

IEYZx2 = X2 -> Z -> Y

$\operatorname{IEYZx} 2=(0,380)+\{(0,560 \times 0,485)\}$ $=0,652$

Based on the results of the analysis, it can be seen that the value of the effect of the direct variable is smaller than the value of the indirect effect, this is due to the indirect influence through intervening variables or there are intermediate variables where the value of indirect effects was obtained from calculations involving direct variable values. Based on the results of t test and path calculation it can be concluded that the sixth hypothesis (H6) which states that Compensation has a significant positive effect on work productivity through job satisfaction and seventh hypothesis (H7) which states that Compensation has a significant positive effect on work productivity through job satisfaction is accepted.

\section{Discussion}

The Effect of Compensation on Work Productivity of PT. Sinergi Mitra Utama "RESPIRO" in Bandung Based on the test results it is proven that workers compensation has a significant direct effect on job satisfaction, meaning that the better the work compensation provided by PT. Sinergi Mitra Utama in Bandung, the higher job satisfaction of employees. As the other hands, if the workers compensation is smaller, it can reduce the job satisfaction of the employee. The hypothesis which states that compensation has a significant positive effect on work productivity, is accepted.

The results of the study show that the employees of PT. Sinergi Mitra Utama in Bandung receive wages every month according to their position. Employees get incentives if they work beyond hours or services outside the city. Employees also get medical benefits from the company and get facilities both physiologically and safely so that employees strive to carry out tasks, improve results, try to be better than yesterday, always develop themselves to improve work skills, strive to improve quality better than who have been past and always do work with efficiency. In addition to those who get the salary, for employees who reach the sales target, they will get $1 \%$ sales incentive for the turnover target of $100 \%$ and $0.5 \%$ if the turnover target is $95 \%$. For new employees during the training period, they certainly get incentives, if the employee keeps visiting out of town, they will get facilities in the form of lodging money, official travel expenses, and food money.

\section{The Effect of Motivation on Work Productivity of PT. Sinergi Mitra Utama in Bandung.}

The results of the analysis show that motivation has a significant positive effect on employee work productivity. The higher motivation of work owned by employees of PT. Sinergi Mitra Utama in Bandung, the work productivity of employees also increased. Likewise, vice versa the decreasing work motivation that employees have, then work productivity also decreases. The results of this study accept the research hypothesis which states that work motivation has a significant positive effect on employee work productivity.

The results of the study indicate that employees feel satisfied. This is evidenced by employees having obtained all physical needs such as bonuses, food allowances, and transportation. Employees also get safety and security facilities in the form of labor insurance, and will be included in the BPJS Labor program. Employees are given the freedom to interact with harmonious working relationships. This is evidenced by no complaints in the company from the workers. Employees also get training. The higher the employee motivation, the SOP applied in the employee company runs accordingly and there are 
no violations. For the problem of PO or DO stock to each store, it is on time due to the motivation.

\section{The Effect of Compensate on Job Satisfaction of PT. Sinergi Mitra Utama in Bandung.}

Based on the test results it is proven that workers compensation has a significant positive direct effect on job satisfaction, meaning that the better the work compensation provided by PT. Sinergi of Respiro Brand Main Partners in Bandung, the higher job satisfaction of employees. Conversely, if the smaller work compensation is received, the lower the job satisfaction of the employee. The hypothesis which states that compensation has a significant positive effect on job satisfaction is accepted.

The results of the study show that the employees of PT. Sinergi Mitra Utama in Bandung get wages every month in accordance with their positions get incentives if they work beyond hours or services outside the city. Employees will also get medical benefits from the company and get facilities both physiologically and safely. The existence of compensation received by employees is shown by being willing to maintain and defend the organization inside and outside the work from undermining irresponsible people. This can be seen from the attitude of employees in facing the offer of competitor companies, employees remain firm in their stance to work at Respiro. Respiro employees have the ability to complete tasks from the company, carry out tasks honestly and carry out their duties honestly. This condition is indicated by the compatibility between the stock of products and deposits and always completing orders on the same day.

\section{The Effect of Motivation on Job Satisfaction of PT. Sinergi Mitra Utama in Bandung}

The results of the analysis show that motivation has a significant positive effect on employee job satisfaction. The higher motivation of work owned by employees of PT. Sinergi Mitra Utama in Bandung, employee job satisfaction also increased. Likewise, vice versa, the decreasing work motivation that employees have, then job satisfaction also decreases. The results of this study accept the research hypothesis which states that work motivation has a significant positive effect on employee job satisfaction.

Feelings related to job satisfaction and job dissatisfaction tend to reflect the assessment of the workforce about current and past work experiences rather than expectations for the future. So it can be concluded that there are two important elements of job satisfaction, namely the work values and basic needs. Job values are the goals to be achieved by carrying out work tasks, an individual will feel satisfied or dissatisfied with his work is something that is personal, which depends on how to perceive the suitability or conflict between his desires and the output (which he got). So that it can be concluded that the notion of job satisfaction is a positive attitude of the workforce including feelings and behavior towards the work through the assessment of one job as a sense of respect in achieving one of the important values of work.

\section{The Effect of Job Satisfaction on Work Productivity PT. Sinergi Mitra Utama in Bandung.}

The results of the analysis show that job satisfaction has a significant positive effect on work productivity. The higher job satisfaction felt by employees of PT. Sinergi Mitra Utama in Bandung, the work productivity of employees also increased. Likewise, vice versa, if job satisfaction decreases, then the work productivity of employees decreases. The research hypothesis which states that job satisfaction has a significant positive effect on work productivity is accepted. Productivity according to Riyanto $(1986 ; 22)$ contains the notion of productivity indirectly stating the progress of the process of transforming resources into goods or suits, an increase means a comparison that rises between the resources used and the number of goods produced. High productivity causes an increase in job satisfaction only if the workforce perceives that what the company has achieved is in accordance with what they receive (salary/ wages) which is fair and reasonable and is associated with superior work performance. This study does not support the research conducted by Muayyad (2016) who found that job satisfaction did not have a significant effect on employee productivity. Whereas Kinasih (2015), found that job satisfaction has an effect on work productivity.

\section{The Effect of Compensation on Work} Productivity through Job Satisfaction of PT. Sinergi Mitra Utama in Bandung.

The results of path analysis show that compensation affects work productivity through job satisfaction. Giving compensation by PT. Sinergi Mitra Utama in Bandung to employees will be able to increase work productivity. This happens because employees feel satisfied with their work. The higher job satisfaction felt by employees, the productivity also increases. So that satisfaction is able to mediate between 
compensation and work productivity. Compensation is often used as a tool to encourage or motivate employees to be more qualified in terms of productivity so the goal of the company will achieved. Therefore, if it is not followed by good compensation, it can reduce employee work.

The results of the study show that the employees of PT. Sinergi Mitra Utama in Bandung get wages every month in accordance with their positions, get incentives if they work more than working hours or out of town, get medical benefits from the company and get facilities both physiologically and safely, resulting in job satisfaction for employees who ultimately employees will strive to carry out the task, improve the results achieved, strive to be better than yesterday, constantly develop themselves to improve their ability to work, strive to improve the quality better than the past and always do work with efficiency.

\section{The Effect of Motivation on Work Productivity} through Job Satisfaction of PT. Sinergi Mitra Utama in Bandung.

The results of path analysis show that work motivation has a significant positive effect on work productivity through job satisfaction. The emergence of work motivation is influenced by several driving factors, both from within and from outside the individual employee itself. Motivation encourages employees to work effectively and efficiently differently among employees. This difference is caused by differences in motivation, goals, and needs of each employee to work, and also due to differences in time and place. Motivated employees will automatically increase their productivity. This is because there is satisfaction felt after being given motivation. If giving motivation is less attention, then there will be no enthusiasm and passion to work. And this will also affect the work productivity of employees.

The results showed that employees had perceptions about PT. Sinergi Mitra Utama in Bandung who have fulfilled the physical needs of their employees such as bonuses, food and transportation money, providing work safety and security facilities in the form of labor insurance, interacting with harmonious working relationships and providing training to employees resulting in job satisfaction and in the end employees are willing to maintain and defend organizations inside and outside of work from undermining irresponsible people, have the ability to complete tasks from the company, carry out their duties honestly and carry out their duties honestly.

\section{Conclusion}

After analyzing the data, several conclusions can be taken, as follow:

a. Work compensation has a significant direct effect on job satisfaction, meaning that the better the work compensation provided by PT. Sinergi Mitra Utama in Bandung, the higher job satisfaction of employees.

b. Motivation has a significant positive effect on employee work productivity. The higher motivation of work owned by employees of PT. Sinergi Mitra Utama in Bandung, the work productivity of employees also increased.

c. Work compensation has a significant positive direct effect on job satisfaction, meaning that the better the work compensation provided by PT. Sinergi Mitra Utama in Bandung, the higher job satisfaction of employees.

d. Motivation has a significant positive effect on employee job satisfaction. The higher motivation of work owned by employees of PT. Sinergi Mitra Utama in Bandung, employee job satisfaction also increased.

e. Job satisfaction has a significant positive effect on work productivity. The higher job satisfaction felt by employees of PT. Sinergi Mitra Utama in Bandung, the work productivity of employees also increased. Likewise vice versa, if job satisfaction decreases, then the work productivity of employees decreases.

f. Compensation affects work productivity through job satisfaction. Giving compensation by PT. Sinergi Mitra Utama in Bandung to employees will be able to increase work productivity.

g. Work motivation has a significant positive effect on work productivity through job satisfaction. The emergence of work motivation is influenced by several driving factors, both from within and from outside the individual employee its self.

\section{References}

[1] Hamali. 2013. Pengaruh Motivasi kerja Terhadap Produktivitas kerja:Studi Kasus Pada

[2] PT. X Bandung. Hasil Penelitian. Journal The Winners. Vol. 14 No. 2. September 2013: 77-86

[3] Handoko T. Hani. 2001. Manajemen Personalia dan Sumber Daya Manusia. Yogyakarta:BPFE

[4] Hasibuan. Malayu S. P. 2009. Manajemen Sumber Daya Manusia. Edisi Revisi. : Jakarta. 
[5] Herzberg. F. 1987. One More Time: How Do You Motivate Employees. Harvard Business Review

[6] Ian Nurpatria Suryawan dan Richard Andrew. 2013. Pengaruh Motivasi kerja Terhadap Kepuasan kerja. Media Riset Bisnis \& Manajemen, Vol. 13, No. 1, April 2013. P54-61

[7] Kadarisman M. 2012. Manajemen Pengembangan Sumber Daya Manusia. Edisi Pertama. Cetakan pertama. Rajawali Press. Jakarta.

[8] Kurnia Setyo Kinasih. 2015. Pengaruh Motivasi kerja, Organizational Citizenship Behavior, Terhadap Kepuasan kerja Dan Kinerja Karyawan Pada PSTA Batan Yogyakarta.

[9] Kreitner dan Kinicki. 2001. Manajemen Sumber Daya Manusia. PT. Bumi Aksara. Jakarta

[10] Luthans. Fred. 2006. Prilaku Organisasi. edisi 10. Yogyakarta: ANDI Yogyakarta.

[11] Mangkunegara Anwar Prabu. 2005. Manajemen Sumber Daya Manusia. PT Remaja Rosdakarya. Bandung.

[12] Manurung, Mandala. 2005. Teori Ekonomi Makro: Suatu Pengantar, Edisi Ketiga, Jakarta: Lembaga Penerbit Fakultas Ekonomi Universitas Indonesia.

[13] Riyanto. 1986. Produktivitas kerja dan Tenaga Kerja. SIUP. Jakarta

[14] Robbins. 2008. Perilaku Organisasi: Konsep. Kontrocersi. Aplikasi. Jilid 1. Edisi Bahasa Indonesia.

[15] Sardiman 2007:73. Interaksi dan Motivasi kerja Belajar Mengajar. Jakarta: Rajawali.

[16] Sarwar, Shagufta and James Abugre. 2013. The Influence of Rewards and JobSatisfaction on Employees in the Service Industry. The Business \& Management Review. Vol.3. No. 2. pp. 22-32.

[17] Sekaran, Uma. 2006. Metode Penelitian Bisnis. Jakarta : Salemba Empat.

[18] Siagian. 2008. Kiat Meningkatkan Produktivitas kerja. Jakarta: Rineka Cipta.

[19] Sikula. 2011. Manajemen Sumber Daya Manusia, Erlangga. Bandung

[20] Sinollah. 2011. Pengaruh Kompensasi Terhadap Kepuasan kerja Karyawan (Studi Pada PT. PLN (Persero) Distribusi Jawa Timur Ap \& J Pasuruan). Jurnal Otonomi, Vol 11 No 1

[21] Simamora Henry. 2004. Manajemen Sumber Daya Manusia. Yogyakarta: SIEYKPN
[22] Singarimbun. Masri dan Sofian Effendi. 2006. Metode Penelitian Survei. Penerbit PT. Pustaka LP3ES Indonesia Jakarta.

[23] Sugiyono. 2008. Metode Penelitian Bisnis. Bandung: Alfabeta.

[24] Sutriani. 2017. Pengaruh Kompensasi Terhadap Produktivitas kerja Karyawan Pada Hotel Afiat Kabupaten Maros. http: //economicsbosowa.unibos.id/index.php/eb/a rticle/view/122

[25] Zuchri Abdussamad. 2014. Pengaruh Kompensasi Terhadap Produktivitas kerja Karyawanpada PT Asuransi Jiwasraya Gorontalo. Jurnal Manajemen/ Volume XVIII, No. 03, Oktober 2014: 456-466. 